\title{
SUSTAINABLE ENTREPRENEURSHIP AND NEW BUSINESS MODELS: A MARKET RESEARCH IN COLOMBIA
}

\author{
EMPREENDEDORISMO SUSTENTÁVEL E NOVOS \\ MODELOS DE NEGÓCIOS: UMA PESQUISA \\ DE MERCADO NA COLOMMBIA.
}

\author{
M. Isabel Sánchez-Hernández ${ }^{1}$ \\ Elena Dorado-Mayorga ${ }^{2}$ \\ Guillermo Alberto Pereira Álvarez ${ }^{3 ; 4}$ \\ Ubeimar Osorio-Atehortúa ${ }^{3 ; 5}$ \\ Sandra M. Malavera-Pineda ${ }^{5}$ \\ Jaime Alberto Montoya-Quintero ${ }^{3}$ \\ 1 University of Extremadura, Department of Business Management and Sociology, School of Economics and Business Administration, Badajoz, Spain \\ 2 National University of Costa Rica, Campus Liberia, Costa Rica. \\ 3 Colombian Polytechnic Jaime Isaza Cadavid, Medellin, Colombia \\ 4 Pontifical Bolivarian University, Medellín, Colombia \\ 5 Catholic University Luis Amigó, Medellín - Colombia
}

\begin{abstract}
Purpose -The aim of this work is to approach the concept of sustainable entrepreneurship from a theoretical and a practical point of view, paying attention to new business models that are emerging around the world for social innovation. In this context, we focus the attention on the business model called one-for-one and we wonder whether the Colombian market should be a good option for developing this business model.

Design/methodology/approach - To test the viability of the business model one-for-one we conducted a market research in March 2019, with a sample of students from two higher education institutions in the city of Medellin (Colombia).

Findings -The results of the empirical research show the positive moral attitude of Colombian to solve social problems, but also the market immaturity because of the relative low purchase intentions found in Colombian potential consumers.

Research limitations/implications - Not exempt from criticism, this work defends innovative business models standing for a business driven concept of sustainability which focusses on increasing both economic as well as social value.

Practical implications - The model of donating one item to someone in need, for each item purchased, could be considered in the future a viable option for developing business models in Colombia.

Social implications - Nowadays and more than never before, society requires that the actions of companies are aimed at contributing to social development and environmental sustainability, as well as economic viability. Companies oriented towards present and future sustainability in the decision making of purchase or investment will be an important source of competitive advantages in the near future.

Originality/value - Although the study of sustainable entrepreneurship is still in very early stages in Latin American countries, this work shed light on the topic analyzing the business model one-for-one as a potential mean to foster a transition towards more sustainable societies.
\end{abstract}

Keywords - Sustainability, entrepreneurship, business models, social innovation, Colombia. 


\section{RESUMO}

Objetivo - O objetivo deste trabalho é abordar o conceito de empreendedorismo sustentável do ponto de vista teórico e prático, atentando para novos modelos de negócios que estão surgindo em todo o mundo para a inovação social. Nesse contexto, foca-se a atenção no modelo de negócio denominado one-for-one e busca-se entender se o mercado colombiano deve ser uma boa opção para o desenvolvimento desse modelo de negócio. Metodologia - Para testar a viabilidade do modelo de negócios one-for-one, realizou-se uma pesquisa de mercado em março de 2019, com uma amostra de alunos de duas instituições de ensino superior da cidade de Medellín (Colômbia).

Resultados - Os resultados da pesquisa empírica mostram a atitude moral positiva do colombiano para resolver os problemas sociais, mas também a imaturidade do mercado devido às baixas intenções de compra encontradas nos consumidores potenciais colombianos.

Limitações/implicações da pesquisa - Não isento de críticas, este trabalho defende modelos de negócios inovadores que representam um conceito de sustentabilidade orientado para o negócio, que se concentra no aumento do valor econômico e social.

Implicações práticas - O modelo de doar um item a um necessitado, para cada item adquirido, pode ser considerado no futuro uma opção viável para o desenvolvimento de modelos de negócios na Colômbia.

Implicações sociais - Cada vez mais, a sociedade exige que as ações das empresas contribuam para o desenvolvimento social e para a sustentabilidade ambiental, bem como com a viabilidade econômica. Empresas orientadas para a sustentabilidade presente e futura na tomada de decisão de compra ou investimentos, serão importantes fontes de vantagens competitivas em um futuro próximo.

Originalidade/valor - Embora o estudo do empreendedorismo sustentável ainda esteja em seus estágios iniciais nos países latino-americanos, este trabalho lança luz sobre o tema, analisando o modelo de negócios onefor-one como um meio potencial para promover uma transição para sociedades mais sustentáveis.

Palavras-chave - Sustentabilidade, empreendedorismo, modelos de negócios, inovação social, Colômbia.

\section{INTRODUCTION}

Sometime ago Richard Branson, the founder of Virgin Group said that we need leadership across multiple disciplines to develop new structures that support for-benefit entrepreneurs and investors who are leveraging business to tackle social and environmental problems. Today, the principles of sustainability are embedding society (BELLUCCI and MANETTI, 2018). The Sustainable Development Goals (SDGs) from United Nations, are a clear call for global action. The 17 broad SDGs, and the 169 targets, want to end poverty, protect the planet and ensure prosperity for everybody in everyplace by 2030 .

In this context, entrepreneurship is a new field of academic research (ÁLVAREZ-GARCÍA, MALDONADO-ERAZO, RÍO-RAMA and SARANGO-LALANGUI, 2019) and a specific topic within this emergent area of research is sustainable entrepreneurship. For sustainable entrepreneurship we refer the processes of identification, exploitation and development of new business opportunities leading to sustainability-oriented ideas for solving social and environmental problems. Considering that the study of sustainable entrepreneurship is still in very early stages, the aim of this study is to approach the concept from a theoretical and a practical point of view in the Latin American context. For this purpose, we must pay attention to new business models that are emerging around the world for sustainable entrepreneurship.

The business model called one-for-one, that consists of donating one item to someone in need, for each item purchased, could be considered as a potential mean to foster a transition towards more sustainable societies. In order to test the viability of this business model in new markets, we have conducted a market study in Colombia in March 2019, with a sample of students from two higher education institutions in the city of Medellin, one public and the other private. 
The chapter is structured as follows. First, it reviews relevant academic literature for sustainable entrepreneurship, sustainable business models and the model one for one. Next, it describes the research design of the empirical study. Thereafter, the study findings are presented followed by discussion, conclusion and suggestions for future research on the topic.

\section{THEORETICAL AND CONTEXTUAL BACKGROUND}

\subsection{THE IMPERATIVE OF SUSTAINABILITY AND SUSTAINABLE DEVELOPMENT}

The schedule of activities towards 2030 has invited in an integral way the entities that are part; both public and private, to carry out joint work for the resolution of the main social, environmental and economic conflicts that affect the community and generate risk factors for the sustainable development of the planet. At the moment a new stage is envisioned in which it is not only the States and the organs of international order that must form a single estate dedicated to transforming the way of thinking and acting of society so that they apply the principles of justice and equity in all its conglomerates, and this direct and unavoidable commitment extends to all the people who live in today's society and especially with those who are part of the academic training in institutions of Higher Education.

Sustainable development began to be discussed in the aftermath of the Earth Summit in Rio de Janeiro in 1992, where the fact that the protection of the environment and the administration of natural resources must be integrated into the socio issues was internationally recognized -economic poverty and underdevelopment. This idea was collected in the term sustainable development, understood as the development that meets the needs of the present, without compromising resources for future generations, meeting their own needs; this concept was designed to meet the requirements of supporters of economic development as well as the requirements of those who are mainly interested in environmental conservation; in addition, the importance of the recognition that education, and specifically Higher Education Institutions, must have in their contribution to the sustainability of sustainable development in all their academic activities.

A few years ago, it has been conceptualized how important Higher Education is with its academic and research contribution in solving relevant problems at the global level, for which it is essential to strengthen the specific areas of management, education and environmental participation in the improvement of the living conditions of citizens. The first significant progress was made in the meeting and declaration of Higher Education institutions on environmental issues and the chairs on the subject that were disseminated in the Seminar and the Bogota Charter in 1985.

The incorporation of environmental issues in the different chairs taught by Latin American universities began in the area of qualification and specific training on the subject and, later, was substantially deepened in institutional management (SÁENZ and BENAYAS, 2015). In Colombia, since the 1991 Constitution, the understanding of the relevance of including the environmental dimension in academic issues is sought. It has been difficult due to the development of interdisciplinary content; and to achieve that, both from the natural and social sciences, general guidelines are proposed from the environmental approach.

Universities have taken great steps in the search for greater understanding and contribution to the strengthening of theoretical educational foundations and provide training in Sustainable Development. In 1993, several institutions supported the idea of creating policies for sustainability in their physical facilities and for this; they managed to sign the University Charter for Sustainable Development, through the European Network of Universities for Sustainability (CRE), where they committed to make a direct and relevant impulse for sustainability from its academic content. In that 
year, the signing of the Kyoto Declaration on Sustainable Development was also achieved, in which it sought that Universities establish an Action Plan for the protection of the environment and sustainable development. In 2002, the Conference of Rectors of Spanish Universities (CRUE) supported the creation of a Working Group to fulfil its commitment to Environmental Quality and Sustainable Development at the institutional level.

The Kyoto Protocol of 1997 was sustained as an international consensus instrument sponsored by the UN to fight against climate change, which is one of the major concerns in which the true dimension and perception of the university student must be sought; The objective was for industrialized countries to gradually reduce their greenhouse gas emissions by an average of $5.2 \%$ in relation to the 1992 level, financial compensation was offered for the fulfilment of the goal and higher education institutions are guarantors of the protection of natural resources against climate change, which is the greatest difficulty of the current era in strictly environmental issues.

Higher Education, research and extension, seek to contribute directly towards the reduction of poverty margins, the achievement of sustainable development and the achievement of the goals proposed in their development plans. It is also important to agree in the local, national and international environment as well as in achieving the challenges posed by the 2030 Agenda for continuous improvement and sustainable development. There are 17 purposes, including number four, "Ensure inclusive, equitable and quality education and promote lifelong learning opportunities for all". Therefore, Higher Education Institutions should seek strategies to make a permanent contribution towards achieving the Sustainable Development goals adopted by United Nations leaders to reduce the levels of poverty, and in turn, protect the planet and ensure general prosperity.

In Colombia, the National Environmental Education Policy substantially states that Higher Education establishments in the country, both official and private, must keep in mind from their policies to their development plans, different academic activities and institutional instances, for the development of Environmental Projects University students (PRAU). Many institutions of Higher Education are in favour of achieving these ends. For example, the University of Medellin as an institution that is immersed in a synergistic territory. It has had several linear approaches to the development of the PRAU since 2007 through the linking of curriculum subjects as classroom projects, related to topics of environmental type in addition to other modalities such as the approach of research seedbeds supported by external entities (such as COLCIENCIAS). It has had also the opportunity to participate in scenarios such as the Inter-Institutional Committee on Environmental Education (CIDEA), the Environmental Training Network, the Latin American Science Forum Environmental (FLACAM).

Since 2002, The University of Medellin has sought consolidation processes to legitimize the University Environmental Project with its development policies, and to achieve this, the Socio-Environmental Dynamics course has been linked to the achievement of classroom projects. Therefore, through the classroom it has been possible to achieve a space for permanent construction of projects, which have been taken into account in a relevant way by the students, both in research projects of research groups and in advanced projects with the support of the entities and/or administrative organizations that have provided spaces for students to get involved and actively participate in it. In addition, tools such as chairs on environmental education have been used that allow to be in the sphere of universities seeking the transformation of scientific and technical knowledge, and of a comprehensive professional training that generates an academic and human potential capable of being an integral part of the taking of decisions, to apply methods and methodologies, allowing the direct impulse the citizen participation towards the achievement of the projects drawn up in environmental matter (LEFF, 1991).

In the same vein, The University of Rosario has endeavoured in its Environmental Management System (SGA) under the dynamics of sustainability, understanding that the development 
of its academic and institutional activities should seek to be healthy from an ecological, socially fair and economically viable point of view, and continue to be so for present and future generations (MUÑOZ, 2004). From this conception, the creation and training of six environmental management programs has been raised: waste, water, energy, air, flora-fauna and environmental education, the latter as the articulating axis of the theme to ensure an education guided by the understanding of the need for sustainable development. The activation of such programs seeks, without a doubt, to make a giant leap from the passivity and conformism of the human being, towards activity and entrepreneurship, in an effort to place the institution as a great promoter of replicable and innovative management models.

All of the above is linked to the participation of the Luis Amigo Catholic University in the environment of the protection of the environment and natural resources and with this it is added that it currently works in collaboration with the Colombian Association of Universities (ASCUN) and other Institutions and networks that drive the development of the 2030 Agenda, through strategies and actions that contribute to its purpose. The last survey conducted by the University and directed by ASCUN, has presented a diagnosis at the institutional level in which it is envisioned that even the road to travel is long, the need to start not only from the diagnosis, but also from the conception of policies oriented to the achievement of the SDGs, which must be energized from each of the substantive functions in fulfilment of the institutional mission, from the formation of human beings with critical and ethical conscience that contribute to the transformation of society. This is reflected in the contribution to ending poverty and hunger, promoting agriculture, water and sustainable energy, promoting well-being at all ages, ensuring quality inclusive and equitable education and promoting learning opportunities, permanent for all, achieve gender equality and empower all women and girls, promote economic growth inclusive and sustainable, full and productive employment and decent work for all, contribute to the development of peaceful cities, economies and sustainable consumption, combating climate change and protecting terrestrial and marine ecosystems.

\subsection{SUSTAINABLE ENTREPRENEURSHIP}

Whereas Economics Theory literature defends that social problems such as inequality (BIRDSALL, 2006; FERREIRA, 2010; RAVALLION, 2011; STEVANS, 2012) and environmental degradation (PANAYOTOU, 1992; MUNASINGHE, 1999; ATKINSON, DIETZ and NEUMAYER, 2007) result from the failure of markets, the role of entrepreneurship in resolving these modern challenges is a new academic topic and subject of research (COHEN and WINN, 2007; DEAN and MCMULLEN, 2007; SCHALTEGGER and WAGNER, 2011; BOONS and LÜDEKE-FREUND, 2013; BELZ and BINDER, 2017).

According to SHEPHERD and PATZELT (2011) the term sustainable entrepreneurship includes other conceptualizations such as eco-entrepreneurship (ARROYAVE-PUERTA and MARULANDA-VALENCIA, 2019) or social entrepreneurship (PERIS-ORTIZ, RUEDA-ARMENGOT and PALACIOS-MARQUES (2016). It is a relatively new in the entrepreneurship ecosystem and is characterized by the formation of a company that contains in its strategic objectives both, economic components such as social development, and environmental protection.

In the same line, the conceptual framework provided by SCHALTEGGER and WAGNER (2011) for describing sustainable entrepreneurship includes various core issues as follows:

- Environmental issues are considered as an inclusive part of corporate sustainability goals.

- Societal change is considered as a non-market goal for sustainable entrepreneurship.

- Sustainable entrepreneurship has to go beyond market, including the basic idea and aim of institutional entrepreneurship linking the market view with the larger societal perspective with a combined market and society perspective. 
It has been assumed that the companies that obtain sustainability integrate their business activities with human, ecological and social objectives in order to benefit the company and the community in general. Sustainable entrepreneurship involves a process in order to achieve sustainable development, through the solution, evaluation and exploitation of opportunities that seek the creation of value that incites social cohesion, environmental protection and economic prosperity. In fact, in responsible societies the commercial, environmental and social entrepreneurship coexist (GUZMÁN and TRUJILLO, 2008).

According to the above, we can say that, in the ecological objectives, we are talking about clean products, that are eco-efficient and with a sustainable technological development that are really responsible and committed to the environment and that improve the quality of life (SCHALTEGGER and WAGNER, 2011). The human objectives have to do with the conduct of companies in social and ethical areas, such as human talent management, human rights, child labour, gender, discrimination, participation of workers for the benefit of the company. This promotes a greater performance in operations making companies more productive because people feel part of it and they create a sense of belonging. It is important to mention that sustainable entrepreneurship allows economic advancement and local development, helping to generate employment, it also contributes to the creation of goods and services collaborating in the growth of communities where these business initiatives generate a favourable impact, with results that facilitate profitability for the entrepreneur (CHIRINOS and MERIÑO, 2017).

To sum up, for many years the objective of the companies was to maximize their benefits, but today must take into account the impact that their activity can generate in society and the environment. Society requires that the actions of companies are aimed at contributing to social development and environmental sustainability, as well as economic viability. Consumers and institutions look at the social and environmental behaviour of these companies to make purchasing decisions, for this reason their economic wisdom oriented towards present and future sustainability in the decision making of purchase or investment has increased. Innovative business models are emerging to accomplish the challenge of sustainability as it is show in the next section.

\subsection{SUSTAINABLE BUSINESS MODELS}

A business model is a tool to delimit and organize key decisions that must be made at the outset of an entrepreneurial venture (MORRIS, SCHINDEHUTTE and ALLEN, 2005). In general terms, and following GOREVAYA and KHAYRULLINA, 2015), designing a business model serves the entrepreneur:

- To conceptualize their original idea, to define it as a concrete set of realistic strategic choices, making the selected choices explicit.

- To establish a logical framework for starting to develop different activity sets to achieve the entrepreneur's goals.

- To describe a way to create, sale and delivery of value to customers.

- To ensure consistency between the business architecture, economics, relationships and growth.

The business model is considered a tool for strategic analysis (MORRIS, 2005) and for managing strategic-oriented choices (SHAFER, SMITH and LINDER, 2005). In recent years, and based on the Model Canvas by OSTERWALDER and PIGNEUR (2010), the traditional business model is being replaced by a sustainable business model. It is evident that many more blocks are modified based on more innovative and sustainable elements in the new business models designed looking for models 
that create circular economy, social and environmental value for stakeholders (CENTOBELLI, CERCHIONE, CHIARONI, DEL VECCHIO and URBINATI (2020).

In order to develop a sustainable and innovative business model, changes must be made in several epicenters that allow generating value for stakeholders, improving the relationship with them, with partners and generating alliances. For instance, The Triple Layered Business Model Canvas developed by JOYCE and PAQUIN (2016) is a tool for exploring sustainability-oriented business model innovation. In fact, it is and extension of the original business Model Canvas by adding an environmental layer based on a lifecycle perspective and a social layer based on a stakeholder perspective.

The sustainable business model strengthens the link between the global strategy and the social responsibility of the business project, innovation is carried out through the entrepreneur initiative and the social change serves as a source of competitive advantage. A good example of a sustainable business model is the model one-for-one.

\subsection{THE BUSINESS MODEL ONE-FOR-ONE}

Nowadays business leaders are showing a most favourable attitude towards social responsibility than never (DIAZ-CHIZ, TAPIA-FRADE and DE DIEGO-VALLEJO, 2019). In this context, the business model one-for-one should be considered at the moment a truly unique business configuration resulting in sustainable advantage. Not exempt from criticism, the one-for-one business model stands for a business driven concept of sustainability which focusses on increasing both economic as well as social value.

The model consists of donating one item to someone in need, for each item purchased. At the moment, the most famous companies adopting this model produce and commercialize necessary items for living such as shoes and glasses. The company helps a person in need with every purchase of one of their products and get a double objective, lucrative and social (SÁNCHEZ-HERNÁNDEZ, 2015).

The main innovation in models one for one is the possibility to add charitable value to the business. The one for one business model can help entrepreneurs to embrace the rise of social entrepreneurship and benefit their businesses. Although this model has emerged in United States, products are sold in countries with high standard of living and also everywhere by electronic commerce. To create a business case for sustainability "requires strategic management to identify, create and strengthen the links between non-monetary social and environmental activities on the one hand and business or economic success on the other hand" (SCHALTEGGER, LÜDEKE-FREUND and HANSEN, 2012, p.98).

The model is not restricted to product based businesses either and other possibilities exist. For instance, a marketing agency could donate consulting hours to an Non Lucrative Organizations (NGOs) or a printing company could donate educational books to communities in need. Thus, the possibilities for implementation are endless.

\section{METHOD}

In order to test the viability of the business model one-for-one in new markets, we conducted a market study in Colombia in March 2019, with a sample of students from two higher education institutions in the city of Medellin, one public and the other private. We used descriptive statistics and a structural equation model to understand the relationship between the variables considered in the study. 


\subsection{CONSUMER BEHAVIOR IN COLOMBIA AND SAMPLE OF THE STUDY}

The Colombian economy is indisputably dependent on raw materials (especially oil, minerals and agricultural products) and, although the country has a long way to go to diversify its production, there are certain sectors on which its economy is based. The country's production is sustained by the domestic demand. According to MORA (2010) around $80 \%$ of total demand is from households and to a lesser extent from the government.

It should be noted, however, that an important aspect that determines the behaviour of the Colombian consumer is given by socioeconomic strata, an element by which it is possible to identify the characteristics, not only of their consumption preferences, but also shows their income. MORA (2010) identified that $55 \%$ of the third stratum is the largest consumer, followed by the low category and finally high with $25 \%$ and $20 \%$ respectively. One way or another, the way of consuming has changed. Nowadays, people are more and more informed and have more alternatives to buy a product. Young people represents $28 \%$ of the Colombian population; that is why it is worth paying attention to the trends of this population. Euro monitor on consumer trends, publishes every year the list of emerging consumer trends in the specific case of young people in Colombia. EUROMONITOR INTERNATIONAL (2019) describes that, according to variables such as the digital transformation and everything that is generated in the day to day of society, shows what will consume and buy.

We assume that the apprentices of the future are acquiring day by day a strong sense of responsibility for others, animals and the environment. Trends such as being vegetarian or vegan, the use of clothing, furniture and organic products are in vogue today. Another global trend is a plastic-free world. The polluting material is not friendly to the consumers of the future. Products unnecessarily wrapped in plastic must seek new alternatives to avoid being rejected. In addition, the advance of the technologies and the communication took giant steps in the last decade and internet has reached the omnipresence and the people do not need to acquire services that generate closeness with their relatives, only the necessary technology. That is extremely important for products one-for-one because e-commerce is the preferred channel for distribution.

Lifestyles change very quickly, and markets must understand this to adapt to modern audiences. From the foregoing, it is clear that solidarity thinking is an essential part of the purchase decision of new generations of consumers, therefore, companies with a vision of solidarity and friendly environment will have a recognition of value that will mark in the minds of their customers bringing as a consequence wealth for all. In the broad sense of the word, it can be said that young Colombians have a great influence on the world economy when it comes to deciding on consumption.

Our study focuses the attention on the university students because they have new trends in lifestyles. We assume that they are conscious consumers. We conducted the research and field work as a research activity in the context of the II International Symposium of Social Innovation in 2019, in Medellín (Colombia). Two universities from the city participated: The Catholic University Luis Amigó and The Politechnic Jaime Isaza Cadavid with a final sample of 75 students.

The Catholic University Luis Amigo, is a private Higher Education Institution, subject to inspection and surveillance by the Colombian Ministry of Education. Its headquarters are located in the city of Medellin, Colombia, and it has offices in the cities of Bogota, Apartado, Manizales, Monteria and Cali. The institution was created and directed by the Congregation of Capuchin Tertiary Religious, San José Province, which includes the territories of Argentina, Bolivia, Brazil, Chile, Ecuador and Colombia.

The origin of the University dates back to the year 1951, with the arrival in Medellin of the Congregation to accompany the process of formation of the minor in difficulty, directing the San José School of Labour. In 1956 the Correctional Psycho-Pedagogy courses, that were approved by 
the Ministry of National Education, begin its activities, which assumes the aforementioned courses. Later, on November 9, 1984, Legal Status No. 17701 was granted and the Colombian Institute for the Evaluation of Higher Education approved the initiation of the Bachelor's Degree in Re-Educational Pedagogy. This is how in 1985 the Luis Amigo University Foundation, FUNLAM, began its academic activities as a Higher Education Institution. At the end of 2011, the Ministry of National Education granted high quality accreditation to the Law and Business Administration programs (face-to-face mode). In 2010 the institution had received the undergraduate of Psychology. On November 10, 2016, the Ministry of National Education, through resolution 2016, granted the character of "University", the highest classification that the Colombian State has for Higher Education Institutions. Today, The Catholic University Luis Amigo offers undergraduate courses in its seven faculties, as well as post-graduate training in specializations, masters and doctorates.

Meanwhile, the Colombian Polytechnic Jaime Isaza Cadavid, is a Colombian University of a public nature and of regional coverage, whose main headquarters are located in Medellin. It is an institution attached to the Departmental Government of Antioquia, founded in 1963. It currently offers Higher Education at the technical, technological and University levels through an offer of undergraduate and postgraduate academic programs in the faculties of Basic, Social and Human Sciences, Audio-Visual Communication, Administration, Agricultural Sciences, Engineering and Physical Education, Recreation and Sports.

The Jaime Isaza Cadavid Polytechnic is considered to be the main technical and technical training centre in the country. For this purpose, it has the Central Campus in the Aburra Valley, located south of Medellin and the Laboratory, Practices and Experimentation Centre, located in the Municipality of Bello.

\subsection{PROCEDURE AND INSTRUMENTS}

A market research is the action or activity of gathering information about consumers' needs and preferences. In order to carry on our market research for products one for one in Colombia, the procedure and instruments were the following.

The field work was developed in the context of the Second Symposium of Social Innovation by RAIS, a ONG from Colombia, in the city of Medellin in the month of March 2019. After a master class, where the business model one-for-one was presented and discussed having as example the pioneer company TOM Shoes, a convenience sample of 75 students answered a questionnaire based on academic literature in the field of Marketing.

To understand the causal relationship between the different constructs considered in the study, we developed the structural model shown in Figure 1 representing the hypotheses suggested by theory. 
Figure 1 - Causal Model



Moral attitude is the independent variable of the model. Recent models of morality have suggested the importance of affect-based automatic moral attitudes in moral reasoning (LUO, NAKIC, WHEATLEY, RICHELL, MARTIN and BLAIR, 2006). At this respect, the Theory of Planned Behaviour considers moral attitude as a positive self-rewarding feelings of doing the right thing and it has been used for instance, for predicting and explaining purchase intentions of organic foods (ARVOLA, VASSALLO, DEAN, LAMPILA, SABA, LÄHTEENMÄKI and SHEPHERD, 2008). Persuasion Theories from the Cause-Related Marketing field have previously studied the factors (such as purchase conditions) and consequences (such as purchase intention) of commercializing cause-products or services (ROYD-TAYLOR, 2007; SAMU and WYMER, 2009). In the same vein, there are also studies analysing the moral emotions of consumers (moral attitude) (YOUN and KIM, 2008; KIM and JOHNSON, 2013) as well as their responsible behaviour (BRØNN and VRIONI, 2001; MOOSMAYER and FULJAHN, 2010).

The hypotheses of this study are the following:

H1: The moral attitude of the potential consumers will impact direct and positively in their purchase intention to buy products one-for-one.

H2: The moral attitude of the potential consumers will impact direct and positively their responsible behaviour.

H3: The moral attitude of the potential consumers will impact direct and positively their purchase conditions.

H4: The responsible behaviour of potential consumers will impact their purchase intentions.

H5: The purchase conditions of potential consumers will impact their purchase intentions.

Following previous work developed by SANCHEZ-HERNANDEZ (2015), the questionnaire presented 5 blocs with a total of 27 the following blocs (Box 1):

- Knowledge - 1 question to know their previous knowledge of the existence of the onefor-one movement;

- Moral attitude - 9 questions to approach the willingness to help people in need;

- Purchase conditions -8 questions to know the conditions required by consumers to buy products one-for-one;

- Purchase intention -4 questions to approach the intentions to buy products one-for-one;

- Responsible behaviour -5 questions trying to discover the behaviour of students as citizens. 


\section{Moral attitude}

I am against inequalities in the world (MORAT1)

I think everyone is against inequalities (MORAT2)

I hate that there are people in need and makes me feel bad about myself (MORAT3)

I feel a moral obligation to help where possible to eradicate inequalities in the world (MORAT4)

I like helping others (MORAT5)

People should help others in the community (MORAT6)

People must help people in need anywhere in the world (MORAT7)

I think that everyone has the right to basic goods and services (MORAT8)

If needed, I would like someone to help me with a one for one product (MORAT9)

\section{Purchase Conditions}

As consumer, I can contribute to the eradication of inequalities (PURCOND1)

I would be willing to buy a one for one product simply because it is necessary to help others (PURCOND2)

To purchase a one for one is important that the price was not high (PURCOND3)

To purchase a one for one is important that the quality was good (PURCOND4)

To purchase a one for one it would be important to find it in stores where I buy regularly (PURCOND5)

To purchase a one for one I need to trust that the product will be donated to those in need (PURCOND6)

To purchase a one for one it is important to know clearly the destination of the product (PURCOND7)

Consumers should be informed of the existence of the products one for one (PURCOND8)

\section{Purchase Intention}

I would buy products one for one if it was easy (PURINT1)

I would buy products one for one by human solidarity (PURINT2)

I would buy products one for one by the personal satisfaction of helping others (PURINT3)

I would buy products one for one to feel that I can be useful to society (PURINT4)

\section{Responsible Behaviour}

Whenever I can I contribute to eradicate inequalities (RESBE1)

When I help someone or I participate in any action to help whenever, I do it selflessly (RESBE2)

I collaborate with NGOs as a volunteer (RESBE3)

I collaborate with NGOs providing money (RESBE4)

When there are natural disasters or specific problems, I usually support providing money (RESBE5)

Source: SANCHEZ-HERNANDEZ (2015)

\section{RESULTS}

As expected, taking into account the novelty of these businesses, only $10 \%$ of the interviewed students of the sample had ever heard about the one-for-one movement. This fact justifies to carry on market studies like this and to deeply study consumer behaviour before entering the Colombian market. We refer both cases, for any one-for-one company consolidated in other markets or before adopting the one-for-one business model for a new venture in this country.

The results of our market research are shown in Graphs 1 to 4. First of all, results reveal very good levels of moral attitude. That is very good because potential consumers are initially, and apparently, positively oriented to help people in need. One-for-one movement needs as consumers very good persons with social values and a collaborative culture. This principles and values are defended by new theoretical positions such as the emergence of an economy of communion (GOLD, 2010) or conscious capitalism (FRÉMEAUX and MICHELSON, 2017). 
Graph 1 - Moral Attitude

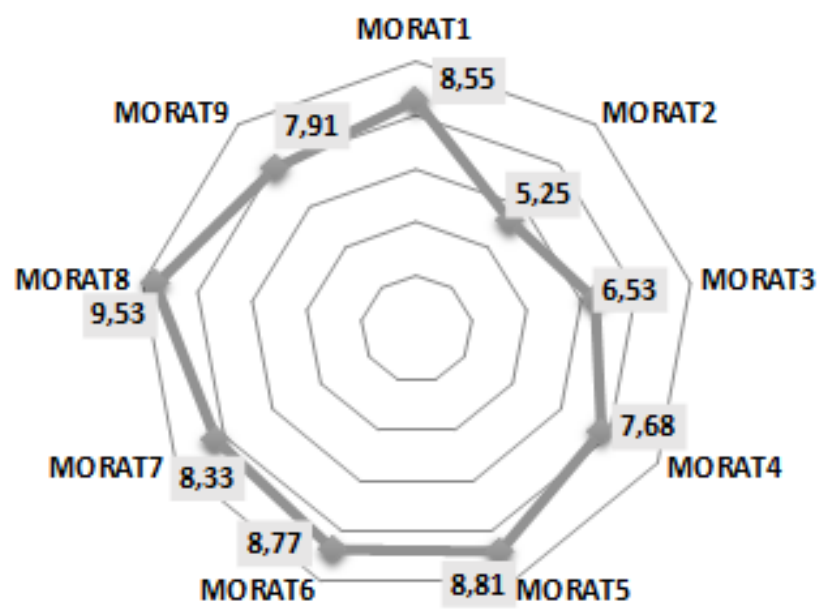

Source: Own

According to the results obtained, potential consumers need very good purchase conditions for acquiring products one-for-one such as good prices or quality.

Graph 2 - Purchase Conditions

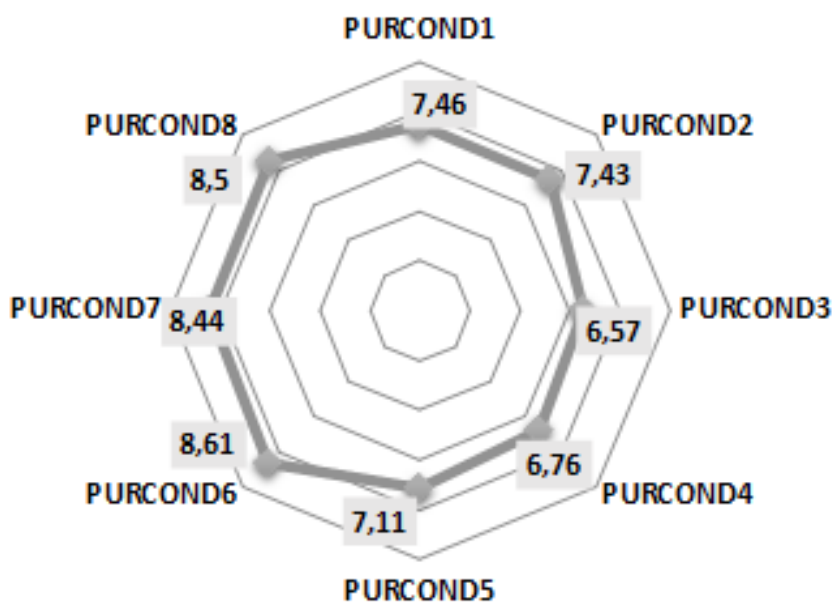

Source: Own

In addition, although students have positive purchase intentions, their behaviour as consumers (purchase intention) and as citizens (responsible behaviour) is not still very high. 
Graph 3 - Purchase Intention

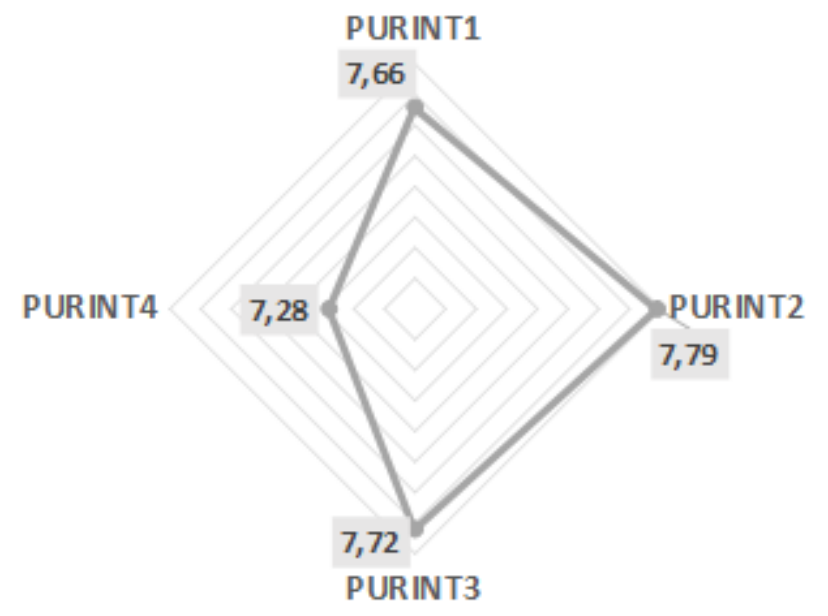

Source: Own

Graph 4 - Responsible Behaviour

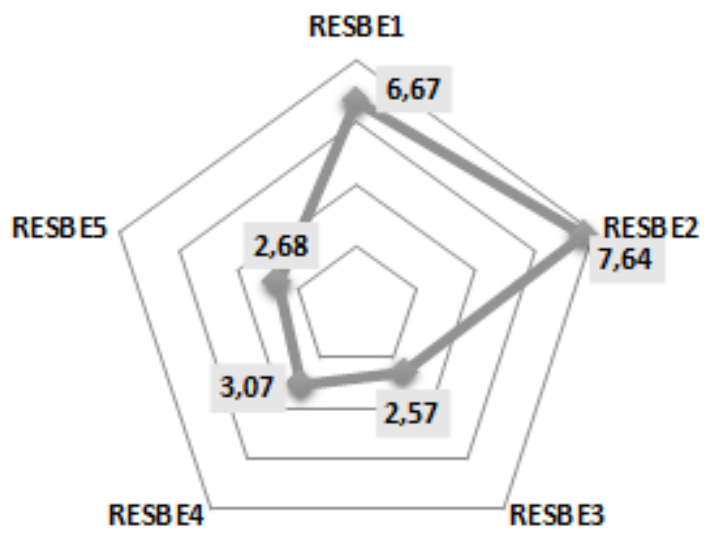

Source: Own

Hypotheses have been tested by using Partial Least Squares (PLS), that is a second-generation structural equation modelling (SEM) technique based on variances, that offers several advantages in the analysis over covariance based techniques. The most important is the possibility to test the model with a small sample, as is the case. SmartPLS 2.0 software has been used to analyse both, the measurement model and the structural model testing the hypotheses from $\mathrm{H} 1$ to $\mathrm{H} 5$ (Figure 2 and Box 2). 
Figure 2 - PLS-SEM Graphical Results

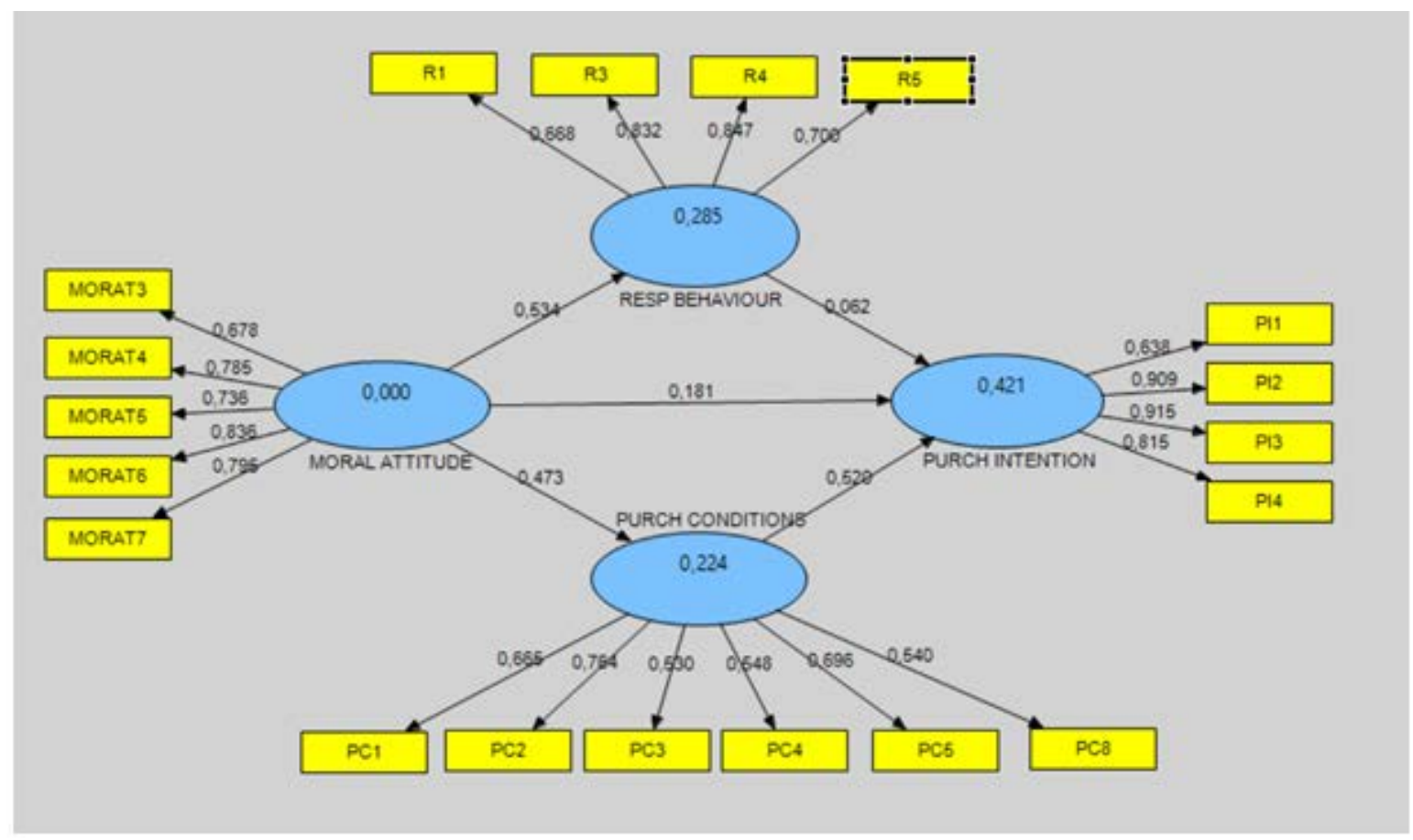

Source: Own

Box 2 - Hiphoteses testing

\begin{tabular}{|l|c|c|c|c|c|}
\hline \multicolumn{1}{|c|}{\begin{tabular}{|c|c|c|} 
HYPOTHESIS / Structural Path \\
A $\rightarrow$ B
\end{tabular}} & $\begin{array}{c}\text { Original path } \\
\text { coefficient } \\
(\boldsymbol{\beta})\end{array}$ & $\begin{array}{c}\text { Expected } \\
\text { Sign }\end{array}$ & $\begin{array}{c}\text { Mean of subsamples } \\
\text { path } \\
\text { coefficients }\end{array}$ & $\begin{array}{c}\text { T -Value } \\
\text { (standard } \\
\text { error) }\end{array}$ & $\begin{array}{c}\text { Supported } \\
\text { Hypothesis }\end{array}$ \\
\hline H1: Moral Attitude $\rightarrow$ Purchase Intention & 0,4600 & + & 0,4604 & $\begin{array}{c}35,65 \\
(0,0129)\end{array}$ & Supported \\
\hline H2: Moral Attitude $\rightarrow$ Responsible Behaviour & 0,5339 & + & 0,5338 & $\begin{array}{c}70,63 \\
(0,0075)\end{array}$ & Supported \\
\hline H3: Moral Attitude $\rightarrow$ Purchase Conditions & 0,4731 & + & 0,4734 & $\begin{array}{c}48,61 \\
(0,0097)\end{array}$ & Supported \\
\hline H4: Responsible Bahaviour $\rightarrow$ Purchase Intention & 0,5198 & + & 0,5197 & $\begin{array}{c}47,42 \\
(0,0109)\end{array}$ & Supported \\
\hline H5: Purchase Conditions $\rightarrow$ Purchase Intention & 0,0616 & + & 0,0614 & 4,52 & Supported \\
\hline
\end{tabular}

Source: Own

\section{CONCLUSION}

From a theoretical point of view, sustainable entrepreneurship contributes to solving problems of society such as children poverty, particularly in emerging and developing countries. Considered as social innovation, the one-for-one movement promotes a new business model consisting of donating one product to someone in need, preferably a child, for each unit sold someone with high moral attitude and responsible behaviour as consumer.

The study was carried on in Colombia, with a sample of university students selected for showing solidarity thinking as consumer trend. But we wonder whether the new generations in South America are willing to pay for sustainability and solidarity. The results of this empirical research in a sample of students in the higher education, with purchasing power, corroborate the good 
moral attitude of the collective under research, but they also shown the relative weak purchase intentions of Colombian students as potential consumers in this market of products one-for-one.

Some theoretical reflexions and practical recommendations for management derive from the study that should be also useful for future new forms of sustainable entrepreneurship. First, sustainable entrepreneurship is still in a very early stage of development and an evidence is the fact that new business models, such as the one-for-one business model, are not very well known. Second, the potential of the Colombian market for this kind of new ventures, and represented in this study by a sample of university students, is not still prepared for this innovation. Third, marketers interested in the one-for-one model have to communicate the advantages of the model and the social innovation that this model represent in order to attract new consumers.

Thus, according to the study, and in line with previous works (e.g. YOUN and Kim, 2008; SÁNCHEZ-HERNÁNDEZ, 2015; PERIS-ORTIZ et al., 2016; ARROYAVE-PUERTA and MARULANDA-VALENCIA, 2019), sustainable entrepreneurship is an opportunity for Latin-American countries and new business models such as the model one-for-one must be better studied for a successful implementation because the Colombian consumers show positive moral attitude to solve social problems but the Colombian market is not still mature for developing one-for-one business.

The results obtained opens a new line of research in cause-related marketing consisting of checking the improvements made by the one-for-one movement in particular, and the social innovators in general, to implement, apply and consolidate their strategies to expand in the market and to enter in new emergent economies such as the Colombian market.

\section{REFERENCES}

ÁlVAREZ-GARCíA, J., MALdonAdO-ERAZO, C.P., RÍO-RAMA M.C., SARANGO-LALANGUI, P.O. (2018). Entrepreneurship and regional development: Study of academic publications in scientific journals (29-51). In: Entrepreneurship and Structural Change in Dynamic Territories. Contributions from developed and developing countries (Editors L Cagica Carvalho, C. Rego, M.R. Lucas, M.I. Sánchez-Hernández, A. Backx Noronha), Ed. Springer.

ARROYAVE-PUERTA, A. M., \& MARULANDA-VALENCIA, F. Á. (2019). Eco-entrepreneurship, sustainability and generation of value. Revista EAN, 87), 155-172.

ARVOLA, A., VASSALLO, M., DEAN, M., LAMPILA, P., SABA, A., LÄHTEENMÄKI, L., SHEPHERD, R. (2008). Predicting intentions to purchase organic food: The role of affective and moral attitudes in the Theory of Planned Behaviour. Appetite, 50 (2-3), 443-454.

ATKINSON, G., DIETZ, S., NEUMAYER, E. (EDS.) (2007). Handbook of sustainable development. Edward Elgar Publishing Limited, UK.

BELLUCCI, M., MANETTI, G. (2018). Stakeholder engagement and sustainability reporting. Routledge.

BELZ, F.M., BINDER, J.K. (2017). Sustainable entrepreneurship: A convergent process model. Business Strategy and the Environment, 26(1), 1-17.

BIRDSALL, N. (2006). Rising inequality in the new global economy. International Journal of Development Issues, 5(1), 1-9.

BOONS, F., LÜDEKE-FREUND, F. (2013). Business models for sustainable innovation: state-of-the- 
art and steps towards a research agenda. Journal of Cleaner Production, 45, 9-19.

BRØNN, P.S., VRIONI, A.B. (2001). Corporate social responsibility and cause-related marketing: an overview. International journal of Advertising, 20(2), 207-222.

CENTOBELLI, P., CERCHIONE, R., CHIARONI, D., DEL VECCHIO, P., URBINATI, A. (2020). Designing business models in circular economy: A systematic literature review and research agenda. Business Strategy and the Environment, 29(4), 1734-1749.

CHIRINOS, Y.D.V., MERIÑO, V.H., MARTINEZ, C.Y., PÉREZ, C.M. (2018). Emprendimiento sostenible para el desarrollo económico de las PYMES. Revista Espacios, 39(7), 3 [In Spanish].

COHEN, B., WINN, M.I. (2007). Market imperfections, opportunity and sustainable entrepreneurship. Journal of Business Venturing, 22(1), 29-49.

CRUE - CADEP (2019). Guidelines for the introduction of Sustainability in the Curriculum CRUE (2011). Recovered from https://www.ucm.es/data/cont/docs/-2012-12-05-Sostenibilidad\%20 curricular.pdf, last accessed 2019/05/19.

DEAN, T.J., MCMULLEN, J.S. (2007). Toward a theory of sustainable entrepreneurship: Reducing environmental degradation through entrepreneurial action. Journal of Business Venturing, 22(1), 50-76.

DIAZ-CHICA, O., TAPIA-FRADE, A., DE DIEGO-VALLEJO, R. (2019) ¿Existe un prototipo de líder socialmente responsable en España?. Cuadernos de Gestión, 19(2), 53-84. [In Spanish].

EUROMONITOR INTERNATIONAL (2019). Consumers life styles in Colombia. Retrieved from https://www.euromonitor.com, last accessed 2019/05/11.

FERREIRA, F.H. (2010). Distributions in motion: economic growth, inequality, and poverty dynamics. The World Bank

FRÉMEAUX, S., MICHELSON, G. (2017). The common good of the firm and humanistic management: Conscious capitalism and economy of communion. Journal of Business Ethics, 145(4), 701-709.

GOLD, L. (2010). New financial horizons: The emergence of an economy of communion. New City Press.

GOREVAYA, E., KHAYRULLINA, M. (2015). Evolution of business models: past and present trends. Procedia Economics and Finance, 27, 344-350.

GUZMÁN, A., TRUJILLO, M.A. (2008). Emprendimiento social: Revisión de literatura. Estudios Gerenciales, 24(109), 105-125 [In Spanish].

JOYCE, A., PAQUIN, R.L. (2016). The triple layered business model canvas: A tool to design more sustainable business models. Journal of Cleaner Production, 135, 1474-1486.

KIM, J.E., JOHNSON, K.K. (2013). The impact of moral emotions on cause-related marketing campaigns: A cross-cultural examination. Journal of business ethics, 112(1), 79-90.

LEFF, E. (1999). Universities and environmental training: ten lines of action. Higher Education and Society, 2(3), 21-25. 
LUO, Q., NAKIC, M., WHEATLEY, T., RICHELL, R., MARTIN, A., BLAIR, R.J.R. (2006). The neural basis of implicit moral attitude-an IAT study using event-related fMRI. Neuroimage, 30(4), 1449-1457.

MOOSMAYER, D.C., FULJAHN, A. (2010). Consumer perceptions of cause related marketing campaigns. Journal of Consumer Marketing, 27(6), 543-549.

MORA, C. (2010). Consumiendo: Introducción al consumidor colombiano. Alfa Omega, Bogotá [In Spanish].

MORRIS, D. (2005). A new tool for strategy analysis: the opportunity model. Journal of Business Strategy, 26(3), 50-56.

MORRIS, M., SCHINDEHUTTE, M., ALLEN, J. (2005). The entrepreneur's business model: toward a unified perspective. Journal of Business Research, 58(6), 726-735.

MUNASINGHE, M. (1999). Is environmental degradation an inevitable consequence of economic growth: tunnelling through the environmental Kuznets curve. Ecological Economics, 29(1), 89-109.

MUÑOZ, A.M. (2004). Sustainable University: conceptual principles for a management system for sustainability. Revista Avances de Tecnología y Producción, 2, 64-78.

OSTERWALDER, A., PIGNEUR, Y. (2010). Business model generation: a handbook for visionaries, game changers, and challengers. John Whiley \& Sons.

PANAYOTOU, T. (1992). Green markets: The economics of sustainable development. Institute for Contemporary Studies, San Francisco, CA.

PERIS-ORTIZ, M., RUEDA-ARMENGOT, C., PALACIOS-MARQUÉS, D. ¿Es posible medir el emprendimiento social en las empresas?. Cuadernos de Gestión, 16(2), 15-28 [In Spanish].

RAVALLION, M. (2011). On multidimensional indices of poverty. The World Bank.

ROYD-TAYLOR, L. (2007). Cause-related marketing: a new perspective on achieving campaign objectives amongst fast moving consumer goods. Strategic Change, 16 (1-2), 79-86.

SÁENZ, O., BENAYAS, J (2015). Environment and Sustainability in Higher Education Institutions in Latin America and the Caribbean. Ibero-American University Magazine in Environment, Society and Sustainability 1(2), 193-224.

SAMU, S., WYMER, W. (2009). The effect of fit and dominance in cause marketing communications. Journal of Business Research, 62(4), 432-440.

SÁNCHEZ-HERNÁNDEZ, M. I. (2015). The One for One Movement: The New Social Business Model. In Innovations in Social Marketing and Public Health Communication (pp. 321-333). Springer, Cham.

SCHALTEGGER, S., LÜDEKE-FREUND, F., HANSEN, E. G. (2012). Business cases for sustainability: the role of business model innovation for corporate sustainability. International Journal of Innovation and Sustainable Development, 6(2), 95-119.

SCHALTEGGER, S., WAGNER, M. (2011). Sustainable entrepreneurship and sustainability innovation: 
categories and interactions. Business Strategy and the Environment, 20(4), 222-237.

SHAFER S.M., SMITH H.J., LINDER J. (2015). The power of business models. Business Horizons 48(3), 199-207.

SHEPHERD, D.A., PATZELT, H. (2011). The new field of sustainable entrepreneurship: Studying entrepreneurial action linking "what is to be sustained" with "what is to be developed". Entrepreneurship Theory and Practice, 35(1), 137-163.

STEVANS, L.K. (2012). Income inequality and economic incentives: Is there an equity-efficiency tradeoff?. Research in Economics, 66(2), 149-160.

YOUN, S., KIM, H. (2008). Antecedents of consumer attitudes toward cause-related marketing. Journal of Advertising Research, 48(1), 123-137. 


\section{AUTHORS}

\section{M. Isabel Sánchez-Hernández}

Economist specialized in Human Resources, Corporate Social Responsibility and Sustainability. Ph.D. in Business Administration (University of Extremadura, Spain), MSc in Economics (University of Aberdeen, UK), MBA in Organization and Human Resources Management (Polytechnic University of Madrid, Spain). Lecturer and researcher in the Department of Business Management and Sociology at the School of Economics and Business Administration.

E-mail: isanchez@unex.es

ORCID : https://orcid.org/0000-0002-6806-1606

\section{Elena Dorado-Mayorga}

Master's Degree in Entrepreneurship and Social Innovation from the University of Salamanca, Spain, and a Bachelor of Business Administration with an emphasis on Marketing from the University of las Americas.

E-mail: elena.dorado.mayorga@una.ac.cr

ORCID: https://orcid.org/0000-0002-0377-9123

\section{Guillermo Alberto Pereira Álvarez}

University Professor at the Colombian University Polytechnic Jaime Isaza Cadavid of Medellín Colombia and the Pontifical Bolivarian University, Industrial Technologist of the Colombian Polytechnic JIC, Industrial Engineer of the University of Antioquia, Specialization in Management of the Colombian Polytechnic JIC, Master in Teaching Education of the University of Manizales .

E-mail: guillermopereira@elpoli.edu.co

ORCID : https://orcid.org/0000-0001-8380-5557

\section{Ubeimar Osorio-Atehortúa}

Industrial engineer and MBA, lecturer and researcher from the Catholic University Luis Amigó in Colombia and also at the Colombian Polytechnic Jaime Isaza Cadavid. He is an industrial engineer and MBA, Manager of the Amigoniana Network for Social Innovation (RAIS), President of the International Corporation of Research and Development in Innovation, Entrepreneurship and Sustainability (CIIDIES).

E-mail: ubeimarosorio@amigo.edu.co

ORCID : https://orcid.org/0000-0003-2493-9007

\section{Sandra M. Malavera-Pineda}

MSc in Marketing Management, from the Catholic University Luis Amigó in Colombia. She is Magister in Marketing Management, with specialization in Senior Management.

E-mail: sandra.malaverapi@amigo.edu.co

ORCID : https://orcid.org/0000-0001-6568-240X

\section{Jaime Alberto Montoya-Quintero}

Master in Organizational Industrial Psychology from the Inter American University, Lecturer and researcher at the Colombian Polytechnic Jaime Isaza Cadavid. Specialised in Management Administration at the University Benito Juárez México, he is Master in Organizational Industrial Psychology by the Inter American University, teacher in postgraduate and undergraduate level.

E-mail: jaimemontoya@elpoli.edu.co

ORCID : https://orcid.org/0000-0001-6382-9041 
Contribution of authors.

\begin{tabular}{|c|c|c|c|c|c|c|}
\hline Contribution & [Author 1] & [Author 2] & [Author 3] & [Author 4] & [Author 5] & [Author 6] \\
\hline $\begin{array}{l}\text { 1. Definition of research } \\
\text { problem }\end{array}$ & $\sqrt{ }$ & $\sqrt{ }$ & $\sqrt{ }$ & $\sqrt{ }$ & $\sqrt{ }$ & $\sqrt{ }$ \\
\hline $\begin{array}{l}\text { 2. Development of } \\
\text { hypotheses or research } \\
\text { questions (empirical studies) }\end{array}$ & $\sqrt{ }$ & & & & & \\
\hline $\begin{array}{l}\text { 3. Development of theoreti- } \\
\text { cal propositions } \\
\text { (theoretical work) }\end{array}$ & $\sqrt{ }$ & & & & & \\
\hline $\begin{array}{l}\text { 4. Theoretical foundation / } \\
\text { Literature review }\end{array}$ & $\sqrt{ }$ & $\sqrt{ }$ & $\sqrt{ }$ & $\sqrt{ }$ & $\sqrt{ }$ & $\sqrt{ }$ \\
\hline $\begin{array}{l}\text { 5. Definition of methodologi- } \\
\text { cal procedures }\end{array}$ & $\sqrt{ }$ & & & & & \\
\hline 6. Data collection & $\sqrt{ }$ & $\sqrt{ }$ & $\sqrt{ }$ & $\sqrt{ }$ & $\sqrt{ }$ & $\sqrt{ }$ \\
\hline 7. Statistical analysis & $\sqrt{ }$ & & & & & \\
\hline $\begin{array}{l}\text { 8. Analysis and interpretation } \\
\text { of data }\end{array}$ & V & $\sqrt{ }$ & $\sqrt{ }$ & $\sqrt{ }$ & $\sqrt{ }$ & $\sqrt{ }$ \\
\hline $\begin{array}{l}\text { 9. Critical revision of the } \\
\text { manuscript }\end{array}$ & $\sqrt{ }$ & $\sqrt{ }$ & $\sqrt{ }$ & $\sqrt{ }$ & $\sqrt{ }$ & $\sqrt{ }$ \\
\hline 10. Manuscript writing & $\sqrt{ }$ & $\sqrt{ }$ & $\sqrt{ }$ & $\sqrt{ }$ & $\sqrt{ }$ & $\sqrt{ }$ \\
\hline 11. Other (please specify) & & & & & & \\
\hline
\end{tabular}

